\title{
Using Activity-Based Costing to Create Transparency and Consistency in Accounting for Division I Intercollegiate Athletics
}

\author{
Heather J. Lawrence, E. Ann Gabriel \\ Ohio University \\ Lauren E. Tuttle \\ KPMG
}

The financial challenges currently faced by NCAA Division I intercollegiate athletics programs have been of interest to academics and practitioners alike. According to the 2004-08 NCAA Revenues and Expenses Report, less than 6\% of Division I athletics programs were profitable each year from 2004 to 2008 (Fulks, 2009). For the other $94 \%$ of programs, there is a reliance on institutional funding to sustain athletic operations (Fulks). Exacerbating this trend, the economic downturn in the United States is forcing institutions to make difficult spending decisions across all campus programs, including intercollegiate athletics. Currently, there are inconsistencies in the accounting practices of intercollegiate athletic departments; especially as those practices relate to allocation of costs (Sperber, 2000; Thelin, 2000; Zimbalist, 2006). The lack of consistency hinders the ability of institutional leaders to make informed decisions about athletics spending. This cross-disciplinary, conceptual paper examines how Activity-Based Costing (ABC), a prominent management accounting cost allocation method, can be applied to NCAA Division I athletic departments. At a time when expenses are outpacing revenues and reliance on institutional support is great, athletic administrators must be armed with accurate information about the costs associated with the operation of each sport program to help in making difficult financial decisions commonplace in today's economic climate.

The financial challenges currently faced by National Collegiate Athletic Association (NCAA) Division I intercollegiate athletics programs have been of interest to academics and practitioners alike. In the most recent NCAA Revenues and Expenses Report, less than 6\% of Division I athletics programs (all from the football bowl subdivision) were profitable each year from 2004 to 2008 (Fulks,

Lawrence is with the Department of Sports Administration, College of Business, Ohio University, Athens, OH. Gabriel is with the School of Accountancy, College of Business, Ohio University. Tuttle is with $\mathrm{KPMG}$, Columbus, $\mathrm{OH}$. 
2009). In the NCAA Division I football championships subdivision and Division I without football, $74 \%$ and $79 \%$ of the athletics revenue came from direct and indirect institutional financial support in 2008 (Fulks). In 2006, over \$1 billion was paid by universities and their students to help support athletic operations (Alesia, 2006). The contribution of athletics to the institution is also substantial. Commonly, athletics is considered the "front porch" of the institution serving as a link between the "immediate campus family and the larger community that includes alumni, fans, supporters and business interests" (Nazarian, 2007,\4 4).

At many Division I institutions, sustaining the operations of the athletic department is difficult even with institutional support and taking into consideration the benefits to the university. In addition to broad cost reduction strategies, athletic departments are being forced to increase the cost of tickets; cut costs by eliminating teams, coaches, and staff positions; and reduce travel, recruiting, salary, and scholarship expenses (e.g., Beseda, 2009; Briggs, 2010; Carrassi, 2009; Hanrahan, 2009; Prunty \& Luicci, 2010). There are a variety of reasons for the reliance on institution support including unavoidable increases in the costs of scholarships, medical and liability insurance, and team travel (Frans, 2002). Employee benefits are also generally out of the control of athletics, yet still greatly impact the budget (Fulks, 2009). Many Division I athletic departments have also chosen to increase spending on recruiting, coaches' salaries, and facility construction in an attempt to be more competitive (McCafferty, 2006). These trends have been exacerbated by recent cuts in higher education funding. In 2009-10, 40 states reported cuts to higher education funding (State Higher Education Executive Officers, 2009). As a result of rising costs and increased spending, expenses are increasing faster than new revenues are generated. The result is more reliance on funding allocated to athletics from the institution (Brand, 2006; Fulks, 2008, 2009; Orszag \& Orszag, 2005).

In addition to the deficits and university support reported by the majority of athletic departments, there are also concerns regarding the consistency and accuracy of the reporting of expenses and revenues in intercollegiate athletics. The Equity in Athletics Disclosure Act (EADA) requires all coeducational postsecondary institutions that receive Title IV funding (i.e., those that participate in federal student aid programs) and that have an intercollegiate athletics program to annually report financial data to the U.S. Department of Education (U.S. Department of Education, 2006). However, reporting requirements (expenses and revenues) are not well defined and Division I athletic departments are inconsistent in their accounting practices (Sperber, 2000). The NCAA also requires financial reporting (NCAA Constitution 3.2.4.16) that is more standardized than EADA data, but only aggregate results are publicly available (National Collegiate Athletic Association [NCAA], 2009). For athletic directors, university presidents, scholars, and the public to better understand the financial state of intercollegiate athletics, a consistent set of accounting practices needs to be established for athletic departments and the resultant data should be shared with the public.

Neither the EADA nor NCAA requires that revenues or costs incurred by athletic departments be allocated or attributed to the individual sports. The development of a cost allocation model for athletic departments would provide a framework in which university presidents and athletic directors can gain a better understanding of the costs associated with sport teams. Cost allocation is a key component of standard corporate accounting practices and the focus of this examination. Revenue 
attribution is also an important component of establishing overall accounting processes, but is beyond the scope of this paper. The prominent cost allocation method in contemporary management accounting is Activity-Based Costing (ABC). Developed in 1988 by Robin Cooper and Robert Kaplan of Harvard University, $\mathrm{ABC}$ is a process for allocating costs that better reflects the usage of resources by each product line than traditional costing methods. $\mathrm{ABC}$ is a proven cost allocation method that has been applied in many settings, including higher education.

The increases in athletic department spending and university support have come at a time when higher education is suffering from reductions in overall funding. Students face increases in tuition and decreases in state supported financial aid at many of the same institutions where athletics receives substantial funding from the institution (Gillus, Upton, \& Berkowitz, 2010). At one major institution, students demonstrated in anger over a $32 \%$ tuition increase concurrent with over $\$ 400$ million in football stadium renovations and a $\$ 2.8$ million salary for the football coach (Chea, 2010; Gillus et al.,). Circumstances such as this are making students, parents, politicians, and the public increasingly active in voicing their concern over how institutional resources are allocated. As institutional pressures for financial accountability mount, athletics will be pressured into tough decisions related to their sport offerings and the support they provide to student-athletes. Being armed with data that accurately reflects the cost of sport programs will allow institutions to make informed financial decisions in these tough times. Furthermore, if all athletic departments are required to allocate their costs according to the same model, financial reports would be more transparent and comparable. The purpose of this cross-disciplinary, conceptual paper is to examine how $\mathrm{ABC}$ can be applied to NCAA Division I athletic departments.

\section{Literature Review}

There is an extensive literature related to the financial challenges facing intercollegiate athletics. Some of the problems identified by researchers include annual deficits, rising costs, excessive spending on facilities, coaches salaries, Title IX compliance, and inconsistency in accounting practices (e.g., Alesia, 2006; Frans, 2002; Fulks, 2008; McCafferty, 2006; Sperber, 2000; Thelin, 2000; Zimbalist, 2006). It is difficult to address these issues without a full understanding of the true costs associated with various segments of athletics operations.

Implementation of $\mathrm{ABC}$ in intercollegiate athletics can increase understanding of costs associated with each aspect of the athletic department as well as improving comparability and transparency. There is also an abundance of theoretical and applied research which focuses on ABC (e.g., Arnaboldi \& Lapsley, 2004; Bamber \& Hughes, 2001; Banker \& Johnston, 1993; Booth \& Balachandran, 1999; Brown, et al., 1999; Byerly et al., 2003; Carducci et al., 2007; Granof et al., 2000; Major \& Hopper, 2005; Jorgensen \& Edwards, 1998; Needy et al., 2003; Zeller, 2000). While $\mathrm{ABC}$ has been applied to many industries, including higher education, it has not yet been applied to intercollegiate athletics. It is possible that $\mathrm{ABC}$ has not been applied in intercollegiate athletics to date because neither the university, NCAA, nor Federal Government have demanded the information that $\mathrm{ABC}$ can provide. Other explanations include that the costs of implementing $\mathrm{ABC}$ have been thought to outweigh the benefits in the past or that there is a lack of awareness of $\mathrm{ABC}$ within college athletic departments. 


\section{Financial Challenges Facing Intercollegiate Athletics}

The financial issues facing intercollegiate athletics are a focus of reform groups (e.g., The Knight Foundation Commission on Intercollegiate Athletics [Knight Commission], The Drake Group, and The Coalition on Intercollegiate Athletics) which are working to provide constructive recommendations to intercollegiate athletics leaders on how to address and overcome current challenges. One of the most notable reform groups in recent years has been the Knight Commission. Since its founding in 1989, the Knight Commission has addressed issues ranging from academic reform to commercialization. Curtailing spending also remains at the forefront of its initiatives (Knight Commission, n.d., 1991, 2001, 2009). The group readily admits that there is still much work to be done and summarizes the problem by stating that, "[a] frantic, money-oriented modus operandi that defies responsibility dominates the structure of big-time football and basketball" (Knight Commission, 2001, p. 17). This attitude in Division I has resulted in significant deficits for most athletic programs.

Between 2001 and 2003, athletic budgets increased 20\% while overall institutional spending increased 5\% (Orszag \& Orszag, 2005). This unsustainable growth was addressed by former NCAA President, Myles Brand (2006) in his State of the Association speech.

The underlying problem is that in Division I over the past several years, on average, the rate of expenditures in athletics has been increasing two to three times the rate of expenditures of the general university. That is not a long-term sustainable approach. These problems mean that the universities will have to increase its subsidy to athletics. Some subsidy, in almost all cases, is required, and that is acceptable (II 78).

In 2008, the NCAA released the 2004-2006 NCAA Revenues and Expenses of Division I Intercollegiate Athletics Programs Report which includes a summary of revenues and expenses of Division I intercollegiate athletics programs for fiscal years 2004, 2005, and 2006. The report differs from previous NCAA financial reports in that, for the first time, revenue is divided into two categories: a) revenue generated by the athletic department and $b$ ) revenue allocated from the institution (Fulks, 2008). The report shows that revenue allocated from the institutions and total athletic department expenses are increasing at a greater rate than revenues generated by the athletic departments indicating a growing dependence on institutional funding (Fulks, 2008). The 2009 report affirms this trend; although at a decreasing rate (Fulks, 2009). Overall, less than $6 \%$ of athletic programs were profitable each year from 2004 to 08 (Fulks, 2009).

A review of the 2004-2005 budgets of 164 NCAA Division I public institutions showed that only $9 \%$ of athletic departments were self-supporting and that over $\$ 1$ billion was paid by universities and their students to help support athletic operations (Alesia, 2006). Without institutional support from student fees, general school funds, and other areas, the average loss of athletic departments would have been \$5.7 million (Alesia, 2006). Even sports programs in Bowl Championship Series (BCS) conferences, generally considered the strongest athletic programs financially and competitively, are losing money. Institutional support becomes an immediate issue when considering that 40 states have reduced their funding levels 
for higher education in 2009-10 (State Higher Education Executive Officers, 2009). The decreased funding for institutions can create greater internal competition for money between university departments.

The financial losses in athletic departments may also have a negative impact on institutions as a whole since money that could be directed to other programs and academic units is instead subsidizing athletics deficits (Alesia, 2006; Brand, 2006; McCafferty, 2006; Sperber, 2000). Many institutions are also absorbing and paying for athletic department expenses such as utilities, maintenance, and debt-service on athletics facilities that are recorded in university accounts (Alesia; Sperber). Covering the annual athletic department deficits with money from the institution's general operating fund, reserve fund, and other financial resources has become common practice. This money, as an alternative, could be used for academic programs, student scholarships and loans, and/or other educational purposes (Sperber, 2000).

\section{Accounting and Athletics}

The federal EADA requires that financial data from all coeducational postsecondary institutions that receive Title IV funding (i.e., those that participate in federal student aid programs) and have an intercollegiate athletics program must report their financial data to the U.S. Department of Education (U.S. Department of Education, 2006). Literature on accounting practices within athletic departments suggests that EADA data are not comparable among institutions due to inconsistency in accounting practices. For example, some athletic departments record utilities, maintenance, and debt-service on the athletic facilities in their own accounts while other institutions record these expenses in their institutions' accounts (Alesia, 2006; Sperber, 2000). Intercollegiate athletic departments also vary as to how costs associated with support services are accounted for. For example, the cost of staff positions such as director of sports information or strength coach may be allocated to all sports programs, allocated at a higher percentage to the sports that benefit and use the resource more, or not allocated at all (Thelin, 2000). Similar inconsistencies between institutions, and even within the same conference, can also be found in the recording of scholarships and coaches' salaries (Zimbalist, 2006). This inconsistency in accounting and reporting practices has led to misleading and incomparable data.

NCAA member institutions are also required by the NCAA to submit financial data to the NCAA (NCAA, 2009). The financial data submitted to the NCAA is based on agreed-upon parameters among NCAA institutions specified in NCAA Constitution 3.2.4.16 to allow for comparisons between institutions. Per those requirements, all revenues, expenses and capitalized expenditures on behalf of an institution's intercollegiate athletics program, including those by outside entities, are reported on annually by an independent accountant from outside the institution (NCAA). State education oversight boards, state accounting procedures, and institutional policy might also require additional reporting for individual institutions. The data collected by the NCAA is more standardized that EADA data, but is not available to the public.

As early as 1988, Skousen and Condie recognized that the accounting models used by athletic departments did not accurately reflect the costs of individual sports. They discuss the allocation of revenues and expenditures among sports using a 
cause-and-effect basis to make decisions about the elimination of sports. Skousen and Condie do not, however, describe a method for allocation. The authors suggest $\mathrm{ABC}$ is the appropriate method for such an allocation.

\section{Activity-Based Costing}

ABC was introduced in the 1980 s as a method to provide more accurate cost information for manufacturing companies (Needy et al., 2003). Traditional cost systems generate cost data that is useful for external reporting, but they do not always provide relevant data for management decisions (Zimmerman, 2000). Generally Accepted Accounting Principles (GAAP) requires products to be valued at full cost. This includes the cost of material and labor directly traceable to the product, plus a fair share of overhead costs. Since overhead costs cannot be traced directly to each product, overhead is assigned, or allocated, to each product on the basis of some measure (Awasthi, 1994).

History and Development of ABC. The demand for management accounting information emerged more than 170 years ago with the creation of hierarchical organizations that invested in their own production processes rather than conducting all business through market transactions (Johnson \& Kaplan, 1987). Traditional costing systems were created in the 1920s when most companies manufactured a narrow range of products and the costs of direct labor and materials, which could be easily traced to individual products, represented the majority of all of the cost to manufacture the product. As overhead represented such a small fraction of total costs, most companies allocated all overhead costs using one input measure such as direct labor. The incurrence of overhead costs was highly correlated with the chosen measure and the distortions from allocating overhead based on one measure were minor. In addition, the cost of collecting additional information to allocate the overhead costs more accurately was too high to justify (Cooper \& Kaplan, 1988).

Given the significant changes in modern manufacturing, Cooper and Kaplan (1988) argue that a single input based measure does not capture the resources consumed to produce a product. As a response, they developed ABC which determines the cost of organizational activities and then traces the cost of these activities to the products or services according to the use of each activity by the products. This is accomplished by capturing overhead costs into overhead pools and allocating them to products based on activities that have a cause-effect relationship with cost occurrence (Brown et al., 1999). In the ABC literature, these are called cost drivers. Traditional costing assumes that products consume resources, while $\mathrm{ABC}$ assumes that products consume activities and activities consume resources (Awasthi, 1994).

$\mathrm{ABC}$ provides more accurate cost information and does not create the distorted data that can result from traditional costing systems. ABC arms decision makers with more reliable cost information so they can make informed decisions about a wide range of strategic options such as dropping product lines, changing prices, or reorganizing operations to find synergies (Cooper \& Kaplan, 1988). Although $\mathrm{ABC}$ is relatively new, its ability to provide a more detailed and relevant analysis of costs for decision-making is gaining recognition as being superior to traditional systems (Morse et al., 2003). 
Although $\mathrm{ABC}$ was created to improve cost allocation processes for large manufacturing firms, it has been applied to many different industries including airline (Banker \& Johnston, 1993), pharmaceuticals (Jorgensen \& Edwards, 1998), government (Brown, et al., 1999), automotive retail (Booth \& Balachandran, 1999), universities (Granof et al., 2000), E-retailing (Zeller, 2000), banking (Bamber \& Hughes, 2001), financial services (Byerly et al., 2003), small manufacturing firms (Needy et al., 2003), healthcare (Arnaboldi \& Lapsley, 2004), telecommunications (Major \& Hopper, 2005) and community colleges (Carducci et al., 2007) along with many others. These applications and work by cost accounting experts have further defined $\mathrm{ABC}$.

\section{ABC Framework}

In general, a cost object is defined as anything to which costs are assigned. Possible cost objects are processes, products, projects, services, and customers. ABC is based on the theory that a) activities performed to fill customer needs consume resources that cost money, and b) the cost of resources consumed by activities should be assigned to cost objects on the basis of the units of activity consumed by the cost object. This two-stage model is the most widely used approach to ABC and Morse et al. (2003) requires that five main steps occur when applying ABC. First, activities are identified. Second, costs are assigned to activities. The assignment of cost can be based on objective data, such as job descriptions or engineering time studies, or subjective estimates based on interviews and questionnaires. The basis for assigning the cost of activities to cost objects can also be obtained through multiple methods, such as direct observation, interviews, questionnaires, statistical analysis, or logical analysis (Morse et al., 2003). Third, the cost driver is determined for each activity. When deciding the basis for assigning costs to cost objects, it is important to determine the proper number of cost drivers. It is important to be accurate, but trying to achieve too much accuracy is a widely recognized reason for failure in attempts to implement ABC systems (Morse et al., 2003). Fourth, the cost per unit of activity is determined. The cost per unit of activity can then be calculated using a simple equation (Cost per unit of activity cost driver $=$ Cost of activity/ Units of cost drivers). Fifth, the activity costs are assigned to the cost object based on the number of units of activity performed for the cost object (Morse et al., 2003).

It is important to note that there is a wide variation in the components of $\mathrm{ABC}$ systems. One uniform system does not fit every organization. The organization has to design an ABC system that best fits its needs and circumstances. This makes the process time-consuming and expensive so a cost-benefit analysis should be conducted (Morse et al., 2003). This will be acknowledged when discussed within the context of intercollegiate athletics.

\section{Cost Allocation in Intercollegiate Athletics}

Although there is some anecdotal evidence and speculation as to the current status of cost allocation in intercollegiate athletics (e.g., Alesia, 2006; Sperber, 2000), there is no data to document prevailing procedures within athletic departments. The requirements of the EADA and NCAA financial reports do not indicate that costs should be allocated to the specific sport programs that they support. 
A 2009 study by Tuttle, Gabriel, and Lawrence provided some insight into cost allocation at institutions in one midmajor division I athletic conference through interviews with athletic administrators responsible for budgeting. They found that salaries, recruiting, team travel, uniforms, equipment, and office supplies were considered direct costs and charged to specific sport programs, but support services (i.e., administration, academic services, business operations, compliance, ticket operations, facility operations, marketing and promotions, sports medicine, strength and conditioning, development, equipment, and sponsorship procurement) costs were not allocated to specific sport programs. In addition, even though the support services were not allocated to sport programs, the athletic administrators stated that some support functions focus on some sports more than others. For example, every interviewee stated that their marketing departments are told to focus their efforts on football and men's and women's basketball. It is expected that some support functions would support some teams more than others. This could be due to team size, inherent sport needs, media pressures, competition schedules, coaches' demands, institutional priorities, or other factors. There was also a lack of consistency in the treatment of scholarships; some athletic departments record scholarships as a direct cost of each sport program while others record scholarships under the general athletic department's accounts. Although accounting mechanisms and some standards are in place through the EADA and NCAA financial reports, neither allows for an understanding of all costs associated with each sport program. It is clear based on this evidence that the true cost of operating each sport program is unknown to the athletic department leadership (at least in this sample) given the current status of cost allocation.

\section{Application of $A B C$ in Higher Education}

Athletic departments are part of institutions of higher education as are academic units, physical plant departments, or ancillary services. Therefore, the application of ABC in higher education as well as in government and nonprofit organizations is applicable to this discussion of $\mathrm{ABC}$ within the context of intercollegiate athletics. The reasons for applying $\mathrm{ABC}$ in these areas include mounting pressures by citizens and elected officials to hold steady or reduce costs, interest in privatizing activities (which calls for comparative cost data), and increased interest in measuring and evaluating performance (Brown et al., 1999). Similarly, institutional officials, the NCAA, reform groups such as the Knight Commission, and the Federal Government are pressuring athletic departments to become more transparent (Knight Commission, 2001; U.S. Department of Education, 2006).

An application of $\mathrm{ABC}$ in a higher education setting particularly relevant to this discussion was conducted by Granof, et al. in 2000. They conducted a case study on the accounting department of the college of business administration of a large public research university. Their purpose was not to develop a complete working model of $\mathrm{ABC}$, but rather to show the feasibility and benefits of applying $\mathrm{ABC}$ in an academic environment. The researchers found that many institutions of higher education previously had either no, or inadequate, costing systems. For these organizations, ABC was the first real measurement system employed, and the primary benefit of $\mathrm{ABC}$ was providing the structure needed for proper accounting. 
Their findings most relevant to this study were that $\mathrm{ABC}$ provides useful cost information and support services do not benefit programs uniformly (Granof et al., 2000). Athletic departments are organized in a similar manner to the college of business accounting department under investigation in that study. Both have administrative and support departments that do not benefit all programs uniformly. The research conducted by Granof, et al. was used as a guide to develop a model for the allocation of these support costs to athletic department sport programs.

\section{ABC Framework for Intercollegiate Athletics}

The work of Tuttle et al. (2009) and a review of institutional websites were used to develop an example of an application of $\mathrm{ABC}$ in intercollegiate athletics. The implementation of a model will vary based on the unique circumstances faced by each institution. Similar to the Granof et al. (2000) study, the purpose of this study is to demonstrate the feasibility and benefits of applying $\mathrm{ABC}$, not to develop a complete working model.

This framework follows the procedures outlined in the two-stage model (Morse et al., 2003). The first step is to identify activities. In athletic departments, the activities are the support functions. Typical activities of an athletic department include administration, academic advising, athletic training, compliance, development, equipment management, facilities and operations, marketing and promotions, media relations, sponsorship procurement, strength and conditioning, purchasing, and ticketing. It should be noted that all of these activities may not exist in every athletic department and there may be other activities not included on this list. In addition, it is becoming commonplace for some of the activities such as ticketing, sponsorship, concessions, and parking to be outsourced to third-party service providers. When activities are outsourced, the athletic department usually receives a percentage of the revenue and there are no costs incurred by the athletic department. In such cases, the revenues should be allocated to the sport which generated the revenue.

The second step of the model is assigning resources consumed to activities. The activities and a list of the resources they consume can be found in Table 1. Many athletic departments already complete this step by recording the costs of each support function, but in $\mathrm{ABC}$, the costs are allocated to the sport programs later in the process.

The third step of the model is determining the cost driver for assigning the resources consumed by activities to cost objects. In athletic departments, the sports programs are the cost objects. The cost drivers can be many different measures including personnel hours, number of tickets sold, number of events, or number of student-athletes. The basis of deciding the cost driver to assign the costs of the support departments can be obtained through observation, interviews, questionnaires, statistical analysis, or logical analysis (Morse et al., 2003). For many of the activities, such as athletic training and strength and conditioning, the time spent by personnel with each sports program is a logical cost driver. For ticketing, the number of tickets sold could be used. The key is finding the cost driver that will most accurately reflect the cost consumed by each sports program. When deciding on any cost driver, there will be some complications. For example, if the number of tickets sold is the cost driver, decisions about how to handle complimentary tickets and season tickets will need to be made. Complimentary tickets should be included 


\section{Table 1 Athletic Activities and the Resources Consumed}

\begin{tabular}{|c|c|}
\hline Activity & Resources Consumed \\
\hline Administration & $\begin{array}{l}\text { Expendable equipment, postage, seminars, courier services, travel, } \\
\text { office supplies, telephone, dues and memberships, books and sub- } \\
\text { scriptions, salaries and benefits. }\end{array}$ \\
\hline $\begin{array}{l}\text { Academic } \\
\text { Advising }\end{array}$ & $\begin{array}{l}\text { Postage, professional development, travel, office supplies, telephone, } \\
\text { orientation, computer laboratory, tutoring personnel, books and sup- } \\
\text { plies, salaries and benefits. }\end{array}$ \\
\hline $\begin{array}{l}\text { Athletic } \\
\text { Training }\end{array}$ & $\begin{array}{l}\text { Expendable equipment, postage, seminars, travel, office sup- } \\
\text { plies, telephone, ice, clothing, tape, protective equipment, medical } \\
\text { supplies, equipment maintenance, medical consultants, medical } \\
\text { expenses, nutritionist, salaries and benefits. }\end{array}$ \\
\hline Compliance & $\begin{array}{l}\text { Postage, seminars, travel, compliance materials, office supplies, tele- } \\
\text { phone, salaries and benefits. }\end{array}$ \\
\hline Development & $\begin{array}{l}\text { Postage, printing, office supplies, telephone, hosting of donor pros- } \\
\text { pects, travel, salaries \& benefits. }\end{array}$ \\
\hline $\begin{array}{l}\text { Equipment } \\
\text { Management }\end{array}$ & $\begin{array}{l}\text { Postage, equipment and supplies, expendable equipment, telephone, } \\
\text { laundry, alternations/repair/reconditioning, salaries and benefits. }\end{array}$ \\
\hline $\begin{array}{l}\text { Facility and } \\
\text { Operations }\end{array}$ & $\begin{array}{l}\text { Postage, security, referee/umpires/officials, announcers, parking } \\
\text { equipment, parking personnel, expendable equipment, custodial, facil- } \\
\text { ity maintenance, office supplies, telephone, radio communications and } \\
\text { headsets, event day equipment, event day staff, salaries and benefits. }\end{array}$ \\
\hline $\begin{array}{l}\text { Marketing and } \\
\text { Promotions }\end{array}$ & $\begin{array}{l}\text { Postage, expendable equipment, seminars, travel, office supplies, } \\
\text { printing, telephone, advertising, salaries and benefits, sponsorship } \\
\text { fulfillment. }\end{array}$ \\
\hline $\begin{array}{l}\text { Media } \\
\text { Relations }\end{array}$ & $\begin{array}{l}\text { Postage, equipment, seminars, travel, office supplies, telephones, } \\
\text { subscriptions, software, photography, pressbox, publications, pro- } \\
\text { grams, salaries and benefits. }\end{array}$ \\
\hline Purchasing & $\begin{array}{l}\text { Postage, expendable equipment, office supplies, telephone, printing, } \\
\text { office machines, salaries and benefits. }\end{array}$ \\
\hline $\begin{array}{l}\text { Sponsorship } \\
\text { Procurement }\end{array}$ & $\begin{array}{l}\text { Travel, sponsor housing, office supplies, telephone, salaries and ben- } \\
\text { efits. }\end{array}$ \\
\hline $\begin{array}{l}\text { Strength and } \\
\text { Conditioning }\end{array}$ & $\begin{array}{l}\text { Postage, weight room supplies, expendable equipment, seminars, } \\
\text { travel, office supplies, telephone, salaries and benefits. }\end{array}$ \\
\hline Ticketing & $\begin{array}{l}\text { Postage, ticket printing, telephone, software, databases, travel, sala- } \\
\text { ries and benefits. }\end{array}$ \\
\hline
\end{tabular}

in total number of tickets sold because they cost the same to produce and distribute as a normal ticket. Season tickets, however, could be counted as one ticket or they could be counted as the number of games included depending on how the athletic department produces their season tickets.

The fourth step in the model is determining the cost per unit of activity. The cost of the activity is divided by the units of the cost driver (Cost per unit of activity 
cost driver $=$ Cost of activity/ Units of cost drivers). For ticketing, the cost of the activity would be the total cost of the ticketing department for the year. If the number of tickets sold is the cost driver, the total number of tickets sold to any event in the year would be the units of the cost drivers. By dividing the total cost of the department by the number of tickets sold, the cost of selling one ticket can be found. For example, if the total cost of the ticketing department is $\$ 200,000$ and the ticketing department sells 800,000 tickets a year, then the costs of one ticket would be $\$ 200,000 / 800,000$, or $\$ .25$ per ticket. Another illustration of this critical aspect of ABC might be related to academic support functions. For some sports, academic support staff travel with the team while others only use the services at a minimal level. In this situation, personnel hours would be the most appropriate cost driver. Assuming the total cost of academic support for student-athletes is $\$ 350,000$ and the total personnel hours in the department are 9,520 (4 full-time employees employed for 52 weeks and 2 graduate assistants employed 30 weeks at $20 \mathrm{hrs} /$ week), the cost is $\$ 36.76$ per personnel hour.

The fifth and final step of the model is reassigning costs from the activity to the cost objects based on the amount of the activities the cost objects consumes. For ticketing this involves multiplying the cost of selling one ticket by the number of tickets sold for each sports program. This would allocate the cost of ticketing to the sports programs that actually benefit for its services. For the ticketing example, if 300,000 tickets were sold for football, the cost allocated to football would be $300,000 * \$ .25$, or $\$ 75,000$. If swimming and diving is not a ticketed sport, their account is not charged anything for ticketing. For academic support, personnel time is assigned to each sport. In this scenario, it is likely that football (with the high number of student-athletes and high demands on academic services) is responsible for half of the total personnel hours $(4,760)$ while women's golf with traditionally strong students and a small number of student-athletes may only use $100 \mathrm{hr}$. Thus, football would be charged $\$ 174,997(4,760 * \$ 36.76)$ while women's golf is charged $\$ 3,676(100 * \$ 36.76)$.

A secondary benefit of $\mathrm{ABC}$ is that mutual monitoring begins to occur because the expenses are relevant to multiple departments. Mutual monitoring, within the context of $\mathrm{ABC}$, is when departments within an organization review expenses incurred by the activity or service department. This review puts pressure on the service departments to perform the activity more efficiently and cost effectively. In athletics, this would occur when the football department questions the ticketing department about its expenses. Representatives from the football department may then observes how ticketing performs its duties to better understand the nature of the expenses. By having this process in place, it is likely that additional cost reductions may occur in ticketing because football is interested in, and is paying attention to, ticketing spending.

Overall, this model can be used to allocate the great majority of costs associated with intercollegiate athletic team operations. While an initial investment in time and resources is needed, once the system is operational it should be no more difficult to manage than most current procedures used in intercollegiate athletics. No framework is perfect, but the benefits derived from understanding the true cost of sport sponsorship are remarkable. Of course, this model is generic and merely identifies the general process of ABC. It must be adapted to the needs and circumstances of each athletic department. Athletic departments should implement ABC 
to make more informed decisions. The positive impact of $\mathrm{ABC}$ on other industries and the relative ease at which it can be applied in athletic departments can improve athletic departments financial reporting. Implementing ABC will allow university and athletic leaders to gain a better understanding of their costs, know the total costs of each sports program, and be able to report accurate and appropriate data that truly reflects costs.

\section{Applications for Intercollegiate Athletics}

When implementing ABC, athletic departments should keep in mind the lessons that others have learned. Many college departments do not have an accounting information system sufficient to support $\mathrm{ABC}$ and restructuring will be required before $\mathrm{ABC}$ can be implemented (Granof et al., 2000). The stronger the existing accounting system, the easier it is to apply $\mathrm{ABC}$; however, the weaker the existing accounting system, the greater the contribution of $\mathrm{ABC}$ (Granof et al.). The cost of implementing ABC should be weighed against the benefits gained from the information $\mathrm{ABC}$ provides. When implementing $A B C$, two sets of costs should be considered. These are the cost of implementing $\mathrm{ABC}$ and the cost of decision error. The cost of changing a cost system can be easily measured, but it is extremely difficult to measure the cost of errors not made because of a better costing system (Awasthi, 1994). The benefit of more accurate information must be estimated and weighed against the cost of changing the system to decide whether to implement ABC (Awasthi, 1994).

Brown, et al. (1999) emphasize that installing $A B C$ is hard work that requires commitment of management. They suggest that a partial and trial use of ABC should precede widespread implementation (Brown et al., 1999). This could be done in college athletic departments by allocating the costs of a few of the activities that consume the most resources first. For example, academic support services and weight room staffing and maintenance could be used as test sites. University and athletic department administrators can evaluate the information gained from this trial. Processes can be refined and activities can be added sequentially.

Flexibility is also crucial when implementing ABC. Every athletic department will have to adapt the model to their specific support departments and determine the cost drivers most appropriate for allocating costs to their sports programs. Many nonaccounting employees will be skeptical of, and even threatened by, attempts to quantify the costs of activities they engage in (Granof et al., 2000). Management's success in overcoming the fear of change in the department will also be vital to success in implementing ABC. They need to ensure that every member of the department is committed to the new system or the department will not realize the total benefits of ABC.

\section{Creating Consistency and Transparency}

A significant hurdle to the implementation of $\mathrm{ABC}$ is that institutions will be averse to applying $\mathrm{ABC}$ if other institutions do not. A possible fear is that $\mathrm{ABC}$ will result in a greater understanding of the high cost associated with some sport programs. The programs that are already known to be expensive such as football will become more expensive if ABC is implemented. Thus, it would be unlikely that a single athletic department would choose to make public financial information which may 
result in a more negative public perception for a single sport program or the entire athletics department.

If either the EADA or NCAA financial reporting began to include cost allocation of some or all of the costs that should be attributed to sport programs, no single institution would be alone under public scrutiny. Since the EADA is currently the only publicly available financial data that is available by individual institution, using $\mathrm{ABC}$ for EADA required reports (within reasonable parameters) would provide transparent and comparable financial data for all institutions subject to EADA reporting for scholars, the public, and institutional leaders alike.

$\mathrm{ABC}$ could also be integrated into intercollegiate athletics financial reporting within the NCAA certification process. If the NCAA membership chose to reinstate the fiscal integrity requirement of the certification process, uniformity would be created across all athletic departments and allow financial information to be compared. At publicly traded companies, accounting standards, such as GAAP, ensure that financial information is fairly stated and increase public confidence in companies (Arens, Elder, \& Beasley, 2008). Accounting standards such as these enforced by the NCAA can accomplish these same outcomes.

\section{Informed Decisions}

In 2007, it was predicted that, "as financial pressures mount, more athletics departments will eliminate sports" (Wolverton, 2007, p. A28). This prediction has become reality at institutions that have eliminated some men's and women's sport teams in recent years such as James Madison University, Ohio University, and Rutgers University (Yiamouyiannis, Lawrence, Ridpath, \& Hums, in press). The consequences of eliminating sports are both monetary and nonmonetary. Given the gravity of the decision to eliminate a sport, $\mathrm{ABC}$ would provide much needed financial data regarding the sport programs to aid decision makers. The authors contend that the real cost savings of the sports being eliminated (generally swimming and diving, wrestling, and track and field) is often overstated within the context of the entire athletic department operations due to a lack of cost allocation within the department.

While there is no perfect system of accounting for any industry, intercollegiate athletics needs to reevaluate its accounting procedures and consider $\mathrm{ABC}$ as a viable alternative. With a greater understanding of the costs associated with each sport, athletic departments will be able to make better decisions, especially decisions about the elimination of sports programs. The time is right to implement ABC. In the past, the costs and challenges associated with beginning to use $\mathrm{ABC}$ might have seemed high. Today, the balance has shifted. The benefits associated with ABC outweigh the costs as athletic departments fight for every dollar they have and their constituents are seeking transparency. The NCAA or federal government (through changes in the EADA) might be the best way to mandate the practice of $\mathrm{ABC}$ and improve comparability, consistency, and transparency in intercollegiate athletics finances.

\section{Future Directions}

There are an abundance of future research opportunities related to accounting and intercollegiate athletics. An informal discussion with a member of an athletic department at very large Division I university suggested that allocation of a greater 
range of costs may be performed by schools who have more resources and a larger accounting staff to properly reflect all resources consumed by specific sports programs. Future research could focus on the differences in cost allocation by athletic departments of different sizes. Application of ABC could also be studied within Division II and III athletic departments. While ABC is concerned with cost issues, Activity Based Management applies similar techniques of identifying key activities within each operating segment of the organization and examining processes and procedures to increase efficiency in operations. Revenue generating activities can be evaluated and revenues generated can be assigned to appropriate sport programs. This is a conceptual paper that focused on the process of cost allocation rather than actual results of an athletic department. Future studies could actually apply ABC at one athletic department to show the actual amounts that should be allocated versus the current understanding of the cost of sport programs.

\section{References}

Alesia, M. (2006, April 30). Colleges pay, public pays. Indianapolis Star. Retrieved from http://www.indystar.com

Arens, A.A., Elder, R.J., \& Beasley, M.S. (2008). Auditing and Assurance Services: An Integrated Approach (12th ed.). Upper Saddle River, NJ: Prentice Hall.

Arnaboldi, M., \& Lapsley, I. (2004). Modern costing innovations and legitimation: A health care study. Abacus, 2, 1-20.

Awasthi, V.N. (1994). ABC's of activity-based costing. Industrial Management (Des Plaines), 4, 8-11.

Bamber, L.S., \& Hughes, K.E., III. (2001). Activity-based costing in the service sector: The Buckeye National Bank. Issues in Accounting Education, 8, 381-408.

Banker, R.D., \& Johnston, H.H. (1993). An empirical study of cost drivers in the U.S. airline industry. Accounting Review, 7, 576-601.

Beseda, J. (2009, October 13). Three seasons in, Jerry Glanville's rebuilding project at Portland State remains daunting. The Oregonian. Retrieved from http://www.oregonlive.com/

Booth, J.M., \& Balachandran, B.V. (1999). Using ABC to identify value: An automotive retailer case study. Journal of Cost Management, 5, 4-10.

Brand, M. (2006, January 7). Brand charts course for collegiate model's next century. [Text from the NCAA State of the Association Speech]. Retrieved from http://www.ncaa. org/wps/portal/ncaahome?WCM_GLOBAL_CONTEXT=/ncaa/ncaa/ncaa+news/ ncaa+news+online/2006/association-wide/brand+charts+course+for+collegiate+mo del_s+next+century+-+1-16-06+ncaa+news

Briggs, C. (2010, February 21). Ticket prices to raise by \$3. The Badger Herald. Retrieved from http://badgerherald.com/

Brown, R.E., Myring, M.J., \& Gard, C.G. (1999). Activity-based costing in government: Possibilities and pitfalls. Public Budgeting \& Finance, 3, 3-21.

Byerly, D., Revell, E., \& Davis, S. (2003). Benefits of activity-based costing in the financial services industry. Cost Management, 6, 25-32.

Carrassi, C. (2009, October 28). Campus loans to athletic department criticized. The Daily Californian. Retrieved from http://www.dailycal.org

Carducci, R., Kisker, C.B., Chang, J., \& Schirmer, J. (2007). Answering the call for accountability: An activity and cost analysis case study. Community College Journal of Research and Practice, 31, 1-17.

Chea, T. (2010, March 5). Angry US students protest cuts to higher education. Yahoo News. Retrieved from http://news.yahoo.com/s/ap/20100305/ap_on_bi_ge/us_university_cuts_protests 
Cooper, R., \& Kaplan, R.S. (1988). Measure costs right: Make the right decisions. Harvard Business Review, 5, 96-103.

Frans, K.A. (2002). Ways in which intercollegiate athletics contribute to university success. North Carolina State University. Retrieved from http://www.lib.ncsu.edu/etd/public/ etd- 737172511021550/etd.pdf

Fulks, D.L. (2008). 2004-2006 NCAA Revenues and Expenses of Division I Intercollegiate Athletics Programs Report. The National Collegiate Athletic Association.

Fulks, D.L. (2009). 2004-2008 NCAA Revenues and Expenses of Division I Intercollegiate Athletics Programs Report. The National Collegiate Athletic Association.

Gillus, J., Upton, J., \& Berkowitz, S. (2010, January 15). Amid funding crisis, college athletics soak up subsidies, fees. USA Today. Retrieved from http://www.usatoday.com

Granof, M.H., Platt, D.E., \& Vaysman, I. (2000). Using activity-based costing to manage more efficiently. The PricewaterhouseCoopers Endowment for the Business of Government Grant Report. New York: PricewaterhouseCoopers, LLP

Hanrahan, S. (2009, October 21). Cal Poly vs. budget cuts. Mustang Daily. Retrieved from http://mustangdaily.net

Jorgensen, S., \& Edwards, M. (1998). Activity-based costing in pharmaceutical development. Drug Development Research, 43, 164-173.

Johnson, H.T., \& Kaplan, R.S. (1987). Relevance lost: The rise and fall of management accounting. Boston: Harvard Business School Press.

Knight Foundation Commission on Intercollegiate Athletics. (n.d.). About. Retrieved March 7, 2009, from http://www.knightcommission.org/index.php?option=com_content\&vi ew $=$ article $\& i d=2 \&$ Itemid $=4$

Knight Foundation Commission on Intercollegiate Athletics. (1991). Keeping faith with the student athlete. Retrieved from http://www.knightcommission.org/

Knight Foundation Commission on Intercollegiate Athletics. (2001). A call to action: Reconnecting college sports and higher education. Retrieved from http://www.knightcommission.org/

Knight Foundation Commission on Intercollegiate Athletics. (2009). Quantitative and qualitative research with football bowl subdivision university presidents on the costs and financing of intercollegiate athletics. Art and Science Group. Baltimore, MD: LLC.

Major, M., \& Hopper, T. (2005). Managers divided: Implementing ABC in a Portuguese telecommunications company. Management Accounting Research, 6, 205-229.

McCafferty, J. (2006). The money bowl: The real competition in big-time college sports is over who can spend the most. CFO Magazine. Retrieved from http://www.cfo.com/ article.cfm/7239613

Morse, W.J., Davis, J.R., \& Hartgraves, A.L. (2003). Management accounting: A strategic approach (3rd ed.). Mason, OH: Thomson South-Western.

National Collegiate Athletic Association. (2009). NCAA 2009-10 division I manual. Indianapolis, IN: National Collegiate Athletic Association.

Nazarian, J. (2007). Front porch deserves care. NCAA News, 44(5), 4.

Needy, K. L., Nachtmann, H., Roztocki, N., Warner, R. C., \& Bidanda, B. (2003). Implementing activity-based costing systems in small manufacturing firms: A field study. Engineering Management Journal, 15(1), 3-10.

Orszag, J., \& Orszag, P. (2005). The empirical effects of collegiate athletics: An update. Indianapolis, IN: National Collegiate Athletic Association.

Prunty, B., \& Luicci, T. (2010, February 24). Seton Hall to cut four sports as part of 'strategic restructuring' plan to stay financially stable. NJ.com. Retrieved from http://www.nj.com/ setonhallSkousen, C. R., \& Condie, F. A. (1988). Goalposts vs. test tubes. Management Accounting, 11, 43-49.

Sperber, M. (2000). Beer and circus: How big-time college sports is crippling undergraduate education. New York: Henry Holt and Company. 
State Higher Education Executive Officers. (2009). State Higher Education Finance: Fiscal Year 2009. Retrieved June 21, 2010, from http://www.sheeo.org/finance/shef/ SHEF_FY_2009.pdf

Thelin, J.R. (2000). Good Sports. The Journal of Higher Education, 71(4), 391-410.

Tuttle, L. E., Gabriel, E. A., \& Lawrence, H. J. (2009). [Cost allocation in division I intercollegiate athletics, a qualitative study]. Unpublished raw interview data.

U.S. Department of Education. (2006). Equity in Athletics Disclosure Act. Retrieved April 12, 2009 from http://www.ed.gov/finaid/prof/resources/athletics/eada.html

Wolverton, B. (2007). The athletics department of the future. The Chronicle of Higher Education, $X X X$, A28.[AUQ4]

Yiamouyiannis, A., Lawrence, H.J., Ridpath, B.D., \& Hums, M.A. (in press).Use of the Responsible Decision Making Model for Athletics (RDMMA) to address conflicting priorities at NCAA Division I member institutions. Sport Management Education Journal.

Zeller, T.L. (2000). Measuring and managing E-retailing with activity-based costing. Journal of Cost Management, 1, 17-30.

Zimbalist, A. (2006). The bottom line: Observations and arguments on the sports business. Philadelphia: Temple University Press.

Zimmerman, J.L. (2000). Accounting for decision making and control (3rd ed.). Boston: McGraw-Hill. 